\title{
The Sexual Throughout the Body of the Tongue
}

\author{
Paulo Sérgio de Souza Jr. ${ }^{1}$ \\ State University of Campinas, Brazil
}

\begin{abstract}
In Fragment 19 of the Harvard Manuscripts, Saussure claims that difference, since it admits degrees, is an uncomfortable term. If anatomy as destiny (Freud, 1912, 1924) is more nuanced than one would like, since it also admits degrees, and anatomical difference does not mitigate the ultimate impossibility of conjugation between speaking beings (Lacan, 1991), how to think of the transit/translation between bodies and where to situate the differences that belong to them? In order to propose an answer, this paper starts from this hypothesis that it is advisable to develop this reflection about sexual difference a couple of feet above the waistline, foregrounding another organ (the tongue), what allows us to critically rethink the entanglement between gender and anatomy in psychoanalysis, in favor of the notion of style.
\end{abstract}

Style is language clearly understood; punctuation is style clearly understood. George Sand (1871/1873, p. 91)

\section{Introduction}

According to etymologists, the Low-Latin word anatomia (anatomy) has traveled through history from the Greek $\dot{\alpha} v \alpha \tau o \mu \eta \dot{~(a n a t o m e \overline{)}), ~ " d i s s e c t i o n ", ~ i t s ~ c o r r e s p o n d i n g ~}$ verbal form $\dot{\alpha} v \alpha \tau \dot{\varepsilon} \mu \nu \omega$ (anatémnō) meaning the act of "cutting into pieces". From this starting point, in several modern languages the term would come to denominate i) the art of dissecting but also ii) the dissected body (the piece of anatomy); iii) the science dedicated to the study and morphology of living, especially human, beings; iv) and also, in a so-called "figurative" sense, "by extension", any kind of methodical investigation (Serça, 2015, pp.173-184). Thus, along its polysemic transit, anatomy is: i) a practice of difference within the body; ii) the result, within the body, of a practice of difference; iii) a body of practices with difference; iv) and an exercise in recognizing the difference that was first distinguished in a practice with the body, regarded as something susceptible to fragmentation, precisely in the interstices where difference sprouts up. However, not all is a bed of roses...

In the Fragment 19 of the Harvard Manuscripts, we shall witness Saussure forgoing any peace of mind by affirming that the difference, much desired as a sound guarantee, consists in a "uncomfortable term", once it "allows for degrees" (Parret, 1995-1996, p. 92). And now, what is to be done? After all, in the field of language, resemblance and difference are tangled up with each other, their nuances mixed up.

${ }^{1}$ Correspondence concerning this article should be addressed to Dr. Paulo Sérgio de Souza Jr., Outrarte, State University of Campinas (SP), Brazil. E-mail: contra_sujeito@yahoo.com.br

Language and Psychoanalysis, 2020, 9 (1), 46-54.

http://dx.doi.org/10.7565/landp.v9i1.1703 
And there is no escaping the fact, which is known to be anxiogenic, that, even though acknowledging the possibility of distinction may seem inevitable, it is also difficult to understand structurally speaking, which elements should be distinguished and in which terms. However, if anatomy as a term (both word or end) seems to have more shades than we would like them to ${ }^{2}$, neither is it possible to categorically deny the suspicion that the differences perceived on the body (its sections) are, first of all, designated by the names they receive. These names, once put forth by a subject and accepted by a few others (Ambra, 2018, pp. 69-70), will in practice mark the first limits of their territory, and thereby determine both what will be inscribed in a certain way and what, in turn, will remain on the sidelines. The verb diferir, which in Portuguese means not only "to differ" but also "to defer" and, at the same time, "to extend", bears witness to this. If these antithetical meanings of a not-at-all-primitive word bring a timeless problem back, it does so because differences, loaded with meaning and producing an anatomized body, establish dynamic and disproportionate limits not only within the body, but mainly within the commerce between bodies. And bodies are haunted by a mythical search in the other for complementarity, for something they cannot find within themselves: we should recall that the myth of the emergence of sexes narrated by Aristophanes in Plato's Symposium tells that a sectioned body is, by all means, a sexed body. That said, how should we regard the traffic (the multiple attempts of access, the intercourses) between theses sectioned/sexed bodies which, to top it all, speak?

To attempt an answer to this question, I start from the hypothesis that it is appropriate to take this reflection about sexual difference to a place situated a couple of feet above the waistline, bringing up another organ, the only exposed internal organ of the human body. Thus, let us speak about a viscus ${ }^{3}$ which, not by chance, short-circuits the inner and outer parts of the organism it inhabits, becoming, in many languages, perhaps the most renowned as well as the most mundane of the catachreses, getting away unnoticed as such: the tongue.

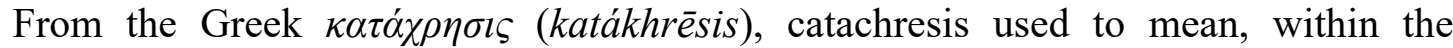
context of rhetoric and figures of speech, using an expression regarded as inappropriate. In Latin, the word was abusio, an "ab-use", a deviant use that, in an act of naming, would arise in order to make up for the inexistence of a specific word. Therefore, it would be possible to identify which named thing had come before and, later on, lent its acoustic image to the one that followed. And thus, it is also assumed that, as for the term tongue, we would be equally capable of pinpointing which organ had been named first: the $\varphi v ́ \sigma ı \varsigma$ (phýsis) organ, internal, so to speak (piece of flesh stretched along the vocal tract and with which a particular species, ours, had the privilege to set itself up to speak), or the vómos (nómos) organ, which stems from the use, the habit, and within which the function of speech is confirmed and conformed: the "formative organ of thought", according to W. von Humboldt (1836, p. 50). However, regarding the tongue, it remains to be seen whether this timeline is possible.

\footnotetext{
${ }^{2}$ After all, it also allows for its degrees. For example, the spectrum of cases of socalled genital ambiguity.

${ }^{3}$ It should be noted that the idea of "viscus", which may be circumscribed in several ways, seems somewhat unclear, even though its purpose seems, in equal measure, rather unquestionable, thus approaching the idea of "word". See Di Dio (1948, pp. 187-198) and Benveniste (1964/1971, pp. 101-111).
}

Language and Psychoanalysis, 2020, 9 (1), 46-54.

http://dx.doi.org/10.7565/landp.v9i1.1703 
After all, if, on one hand, the historical preexistence of the biological body in relation to language might lead to the belief that it was precisely the emergence of languages that enabled several of them to name themselves as such, in the same way they had previously named the organ; on the other, we are confronted with a circularity as soon as we notice that nothing can be named before there is a language that makes it possible to name anything. Thus, even though we may assume that every name emerged as a proper noun - or, in accordance with the tradition in Arabic grammar, literally a "flag-noun": إسم علم (ism 'alam) - the very act of naming carries within itself an impropriety. After all, in the field of deixis, a pure act of indication, we find a gesture pointing to an object that, if anything, allows itself to be indicated, but recedes at the slightest attempt at touching and completely circumscribing it, expropriating itself, so that the object has forever been lost. This means, at the very least, guaranteeing that there is no Other of the tongue, because the very tongue is always Other, even the $\mathrm{m}(\mathrm{O})$ ther tongue; and that the syntagm "foreign tongue", for instance, is pleonastic, once that every tongue is heterogeneous/extraneous/foreign to what becomes a name within it. That said, every tongue is, as a matter of principle, an impropriety and, in the extended sense of the term, a constellation of catachreses: as Quintilian used to say (Institutio Oratoria, 8.6.35), when something bears no name and the name of something that is perceived as similar is extended to it, i.e., when one commits an abusio by generalizing a designation, by situating it within a generic constellation. However, when defining abusio, the grammarian also says that the deviant use ought to be differentiated from the usage of a name that exists in place of another which also exists: in this case, it would be within the realm of translatio, which the Greek language referred to as $\mu \varepsilon \tau \alpha \varphi \rho \rho \alpha$ (metaforá): transportation andwhy not?-transference. Therefore, if the tongue institutes itself in the abuse (from nothing to name), it is put into practice in translation (from one name to the other): a practice in speech and writing, but also a practice in listening and reading.

Here, when we say tongue, we are talking about this tongue that preceded us, which is in constant change, and was transferred to us from others, which, in turn, received it from other others. A tongue which we were invested with, which gave us a voice and taught us, by force, to invest the body at our disposal in a particular way, providing us with the opportunity to inhabit it, as it has been loaded with the gestures of speech and with the borders they draw (with the senses and nonsenses they single out) ${ }^{4}$. A tongue that corrupts the objects and that, whilst spoken, speaks us: just one slip of the tongue is enough and no sooner said than done (it tells on us and there is no tonguein-cheek). But also a sharp tongue that profanes itself (in the infamy of mistakes, in the prestige of poetry) and breaks the silence it soon learns to violate. Likewise, the tongue has also been acknowledged as the very object of retaliation for transgressions which some were, for some reason, trying to silence. For instance, during the $16^{\text {th }}$ century Reformation, within the context of torture methods aimed at silencing women in particular: executioners "prepared two little irons between which the tongue was screwed, which being seared at the tip with a glowing iron, would swell to such a degree, as to become immoveable, and incapable of being drawn back" (Brandt, $1671 / 1720$, p. 275). Or as in Germany, Spain and Italy, where there were accounts of

4 "Evolution has made of us the only primates capable of hearing gestures that may, in a variety of ways, point to other gestures, inaudible but full of meaning" (Albano, 2001, p. 179).

Language and Psychoanalysis, 2020, 9 (1), 46-54.

http://dx.doi.org/10.7565/landp.v9i1.1703 
a practice that punished offenders by piercing their tongues with a fiery iron rod (Portal, 1770, pp. 310-311).

Between attempts at dialogue and attacks which, at all times in history, sought to create an obstacle to communication (more or less literally), it seems that the body of the tongue has frequently been an object of attention. If intercourse is precisely a term that carries within itself both senses of communication and sexual relations, maybe it is not a coincidence that, in many cultures, the presence of tongues in the act of kissing is so prevalent; or the power, on the order of separation, of a tongue stretched out of the mouth, solitary and exhibited to others, constituting a sign of mockery (for the adult) or a serious offense (for the child). And with the notion of intercourse we once again find the translatio mentioned by Quintilian: the metaphorical translation, the copulation between the terms of that which aspires to be a relationship or, so to speak, a counterpoint (as in music, when a melody is added as accompaniment to another). If every tongue, as a constellation of catachreses, is founded in abuse, it is practiced during intercourse. Thus, it is during dialogue that the other's tongue is transformed into our own, transforming ourselves in the process, therein marking not only a discrepancy between one and oneself (after all, the speaker may see themself, beyond the mirror, as a third person), but also placing the human, which is subject to that, within constellations of possible similarities with other elements, which were named and grouped in advance according to the presence or absence of characters that were given meaning throughout history, and through which they are read, immediately at times. At the time of birth —or, due to technical advances, even before that - the subject to be, endowed with their characters, is, first and foremost, a subject to be read; and, at first, nothing can be done to counter this reading. Let us call these letter constellations, based on which the subject is read and positioned, genders.

"Genders" in plural, since they are many. From a broader viewpoint, grouped within the constellation of those who speak, for instance, we (of the human gender) see ourselves as capable of creating the world in the image of our likenesses. If the catachresis, a deviant use, will be in charge of naming in an extensive way, it is not surprising that the generalization one's own body will find a breeding ground therein: on the "head of a nail" or at the "foot of the page", it is the human body that, whilst fragmented, finds a direction through which to extend itself ${ }^{5}$. And thus, the genders also extend to words. However, Brazilian Portuguese speakers should not naturalize that grammatical genders may get mixed up with the masculine and the feminine, though they invariably do and though they are in fact capable of infesting the imaginary of any given speaker (Jakobson, 1959, pp. 232-239; Lakoff, 1987). There is no need to have a certain interest towards, for example, German (in which "miss", Fräulein, is gender-neutral) or Russian (in which "man", мужчина [muzhchína], despite being a masculine noun, is morphologically constituted as well as declined according to the paradigm of the feminine) in order to reflect upon the fact that bolso ("pocket" in Portuguese) is not exactly more masculine than bolsa ("handbag" in Portuguese). The examples here are numerous. Nevertheless, we should not even naturalize the notion of grammatical gender as being attached to the classical bipartition between masculine and feminine, as demonstrated not only by German and

\footnotetext{
${ }^{5}$ An example of this is the 个 ( $\left.g \grave{e}\right)$ in Mandarin Chinese, which is mainly used in reference to people and easily replicated to words of different genders, especially in informal situations.
}

Language and Psychoanalysis, 2020, 9 (1), 46-54.

http://dx.doi.org/10.7565/landp.v9i1.1703 
Russian (with their neuter genders) or Romanian (with its neuter, which is a peculiar mixture between masculine and feminine), but also Chinese and several indigenous languages of the Americas, in which genders are frequently grouped around characteristics such as form and function.

What is at stake, then, in dealing with this anatomy of the tongue is that these elements, available within the body and the language, boiling over in the cauldron of history, eventually sink in different severing possibilities and, of course, prompt the imaginary. However, from the moment they take on a meaning, leaving the pure empire of catachreses and migrating to the world of metaphors, to interpret them as destiny (term, end, target) hangs on how we distinguish the subject's function as that which is read or which, at times, makes itself capable of writing: as one who punctuates that which is written about oneself. Thus, towards their bodies and their characters, as well as towards the act of writing (the writing itself regarded precisely as a set of characters), there are at least two possible exemplary attitudes. The first one, so to speak, would be falling into the so-called Arabian fatalism, the legendary مكتوب (maktub, "it's written"), or even, with regard to characters, wanting to be not only normative but also universalistic: Leibniz's characteristica universalis, for instance. In this sense, it is a well-known fact that Didot, an embodiment of the $19^{\text {th }}$ century typographic thinking, punctuated in the same way every text that fell under his responsibility, as if resuming Beauzée's conclusion on the entry "Punctuation" in Diderot and D'Alembert's Encyclopedia: "it would be desirable that, in whatever language the books printed today were written, editors introduced the system of punctuation used in all living languages in Europe" (Beauzée, 1765, p. 24).

In April 1876, proceeding in that direction, in the $137^{\text {th }}$ edition of L'Imprimerie, a French magazine devoted to typography and lithography, the editorial declared that "punctuation is the anatomy of language and thought" and that "to punctuate is to dissect the phrases". Based on logic, punctuation would thus be universal: valid, therefore "for languages of all times and all countries, applied, without any distinction, to Greek, Latin, Italian, Spanish, English, German and French" (Lorenceau, 1980, p. 52).

The typographers [who wrote the aforementioned editorial] may certainly aim at the figurative sense, and thus we think of what the school tradition called the "logical analysis" of the sentence; but, above all, we think of the autopsy, the anatomy plates, these representations of the écorchés, which reveal the inner structure of a body — of a dead body. (Serça, 2015, pp. 173-184)

We are definitely not talking about dead bodies here; in the same way this is about living tongues. And if according to Whitehead-author, along with Russell, of the renowned Principia mathematica- "life lurks in the interstices" (Whitehead, $1929 / 1978$, p. 105), it is to be expected for Sand to say, sparking off a hostile reaction 
from typographers of that time, that "a correct distribution of stops requires tact", which "are not within the province of the proof-reader" (Sand, 1871/1873, p. 96). George Sand, the enigmatic pseudonym of Amantine-Lucile-Aurore Dupin (Sand, 1856 , p. 45), argues for the possibility, within the ambit of characters, of a punctuation - thus, of an anatomy of the language, according to typographers - that is in line with fantasy and tact, open to the desire of the one who writes and that, like her, wishes to be read; wishes to be read in a certain way. And what her very own public presentation as cross-dresser was capable of pointing out, during the first half of the $19^{\text {th }}$ century, was that the experience with one's own body and with the body of the other, in the level of their various characters, is culturally punctuated (so that the body, like the text, may be presented with distinct punctuations in different civilizations, tongues and eras) but is also punctuable: in the most diverse senses of the term, Sand, regarded as the first woman who lived off her own royalties, made herself read in the masculine (Sand, 1856, p. 5). Once the elements are given in the condition of a mark, they still do not find themselves hindered from being punctuated according to the likes of the speaker's fantasies, who includes points that are capable of supporting their desire and, thus, throwing the dice for, on contingency, opening themselves up to the possibility of encounters and altercations: the so-called intercourses between bodies, always im-probable, in the sense that they cannot be proved $^{6}$. The composer Frédéric Chopin, for example, maintained a relationship with George Sand for almost his entire stay in Paris, creating a "musical-literary, political and gender counterpoint" (Wisnik, 2013, p. 19).

Finally, the intercourses present one dimension of the politics of traces, of characters which, with the aid of psychoanalysis, may be thought of as a poli-tikhe : politics as the management of multiple chance events, each with their own destiny ( $\tau \dot{v} \chi \eta)$, which translates from Greek to German as Schicksal. Not by chance, the Napoleonic statement that "politics is destiny" is precisely what Freud claims to be paraphrasing when making the notorious assertion that "anatomy is destiny" [die Anatomie ist das Schicksal], a formulation that appears in writing in two moments of his work: "On the Universal Tendency to Debasement in the Sphere of Love" (Freud, 1912/1970, p. 209) and "The Dissolution of the Oedipus Complex" (Freud, 1924/1970, p. 249). The context for that statement borrowed by Freud seems to be paramount however (Moi, 2001, pp. 374-377).

The year is 1898; more precisely, September. Napoleon and Goethe meet in Weimar. The subject: theater; more precisely, the gothic melodramas, which were popular by the end of the $18^{\text {th }}$ century, the so-called "destiny plays (Schicksalsstücke)" (Goethe, 1808/1952), p. 1416). According to Goethe's notes on that conversation, Napoleon completely disapproves of this kind of play, since they supposedly belonged to dark times: "What does one want destiny for now?", he asks, following with: "Politics is destiny". "Destiny", what an uncomfortable term! Whether in the gothic melodrama or the classical tragedy, I would like here to raise the question: would it not be better, in order to set up a discussion about anatomy starting from the psychoanalytical experience-i.e., from a certain experience with language - to think of another term to translate Freud who translated Goethe who translated Napoleon who, as history

${ }^{6}$ Note: according to Lacan (2011), the sexual act does not exist precisely because it cannot be written.

Language and Psychoanalysis, 2020, 9 (1), 46-54.

http://dx.doi.org/10.7565/landp.v9i1.1703 
shows, did not translate anyone who did not recognize the imperious insignia on his uniform?

If Freud says that the goal/intention/purpose of life is death by using the term Ziel (Freud, 1920/1975, p. 248), why not think about Schicksal, through which echoes the verb schicken (to send), not so much like destiny or end, but as the fate that is devised along the way. Or, better yet, as they say in the theater, the denouement that, taken literally, is precisely the opposite of a closure? Therefore, even delving into the origins did not freeze Freud in the past, since he was capable of foreseeing, in the myth and the primeval, the possibility of thinking the present of the clinic to which he dedicated himself and the theory underpinned by it. As psychoanalysts, would it not be precisely the opportunity we present: that in building an analytical path the transference investment might be capable of connecting the fragments of that which is primary with a future that, from then on, is rebuilt? Therefore, the clinic would be nothing less than an investment in possible recombinations within the original experience on behalf of a subject development that is less stagnant in the midst of their circumstances, through building the ability to deal with one's own marks and acting on them.

Characters, marks, insignia: limits with which we must cope, but also emblems capable of sending, communicating, remitting to the other the history of those who create and, with more or less pride, carry them. In the body of the text or the text of the body that is written in order to be read therefore lies the compulsoriness of an act of addressing, of sending, which is articulated with contingencies of style and of all that is made possible by techniques and artifices. A style that, as an incision, also lurks in interstices, just like life; a style that, although may seem to be resisting alterity, is constituted by it. We shall remember, after all, that Lotman (1996/1999, p. 58) defines the trope (the figure of speech, the figure of style) as "a mechanism for constructing a content which could not be constructed by one language alone" since it is "a figure born at the point of contact between two languages"; and Lacan (1960$61 / 1991$, p. 372) connects the idea of trope to the idea of destiny by saying that destiny "is the trope par excellence, the trope of tropes". And if Lacan, while translating Buffon for an audience that was his own, said that "style is the man to whom one addresses oneself" (Lacan, 1966, p. 9), a hundred years before Sand anticipated an adage that would still take a while for Freud, then a teenager, to eventually understand and which not even Lacan, to the best of my knowledge, has ever commented on: "punctuation is much more the man than style is" (Sand, $1871 / 1873$, p. 920). There is an adage we might gain from bringing back; us, who have translated Lacan who translated Buffon, but still face a bit of challenge-we must admit - in translating George Sand and many others who, with their brave truths, dared to translate themselves through the course of their own histories.

\section{References}

Albano, E. C. (2001). O gesto e suas bordas. Campinas, Brazil: Mercado de Letras. Ambra, P. (2018). Des formules au nom: bases pour une théorie de la sexuation chez Lacan. In Analysis, 2, 69-70. 
Beauzée, N. (1765). Ponctuation. In Diderot, D., \& D’Alembert, J. le R. (Eds.), L'Encyclopédie ou Dictionnaire raisonné des sciences, des arts et des métiers, vol. 13 (p. 24). Neuchâtel, France: Samuel Faulche. Retrieved from www.biodiversitylibrary.org/item/176491\#page/23/mode/1up

Benveniste, E. (1971). The levels of linguistic analysis. In Problems in general linguistics (pp. 101-112). Coral Gables, FL: University of Miami Press. (Original work published 1964)

Brandt, G. (1720). The history of the reformation and other ecclesiastical transactions in and about the low-countries, from the beginning of the eighth century, down to the famous synod of Dort, Inclusive, vol. 1. London, England: Printed by T. Wood for T. Childe. (Original work published 1671)

Di Dio, L. J. A. (1948). Generalidades sobre a esplancnologia. Conceito de víscera. Revista de medicina, 32(173-6), 187-198. Retrieved from www.revistas.usp.br/revistadc/article/viewFile/57587/60643

Freud, S. (1970). Über die allgemeinste Erniedrigung des Liebeslebens (Beiträge zur Psychologie des Liebeslebens II). In Studienausgabe, vol. V (pp. 197-209). Frankfurt am Main, Germany: Fischer. (Original work published 1912)

Freud, S. (1975). Jenseits des Lustprinzips. In Studienausgabe, vol. III (pp. 213-272). Frankfurt am Main, Germany: Fischer. (Original work published 1920)

Freud, S. (1970). Der Untergang des Ödipuskomplexes. In Studienausgabe, vol. V (pp. 243-251). Frankfurt am Main, Germany: Fischer. (Original work published 1924)

Goethe, J. W. von (1952). Unterredung mit Napoleon. In Goethes poetische Werke, vol. 8 (pp. 1417-1421). Stuttgart, Germany: Cotta. (Original work published 1808)

Humboldt, W. von (1836). Über die Verschiedenheit des menschlichen Sprachbaues und ihren Einfluss auf die geistige Entwicklung des Menschengeschlechts. Berlin, Germany: Dümmler.

Jakobson, R. (1959). On linguistic aspects of translation. In On translation (pp. 232239). Cambridge, MA: Harvard University Press.

Lacan, J. (1991). Le séminaire, livre VIII: Le Transfert [1960-61]. Paris: Seuil

Lacan, J. (1966). Ouverture de ce recueil. In Écrits. Paris: Le Seuil, 9-10

Lacan, J. (2011). Le séminaire, livre XIX: ...ou pire [1971-72]. Paris: Seuil

Lakoff, G. (1987). Women, fire, and dangerous things. Chicago, IL: University of Chicago Press

Lorenceau, A. (1980). La ponctuation au XIXe siècle. Langue française, 45, 50-59

Lotman, W. M. (1999). Внутри мыслящих миров: человек-текс-семиосфераистория. Moscow, Russia: Языки русской культуры. (Original work published 1996)

Moi, T. (2001). Is anatomy destiny? Freud and biological determinism. In What is a Woman? And other essays (pp. 374-377). New York, NY: Oxford University Press.

Parret, H. (1995-96). Réflexions saussuriennes sur le temps et le moi: Les Manuscrits de la Houghton Library à Harvard. Cahiers Ferdinand de Saussure, 49, 85-119.

Portal, A. (1770). Histoire de l'anatomie et de la chirurgie. Paris, France: P. Fr. Didot.

Sand, G. (1856). Histoire de ma vie, vol. 1. Paris, France: M. Lévy.

Sand, G. (1873). Lettre à Charles-Edmond. In Impressions et souvenirs (pp. 91-106).

Paris, France: Michel Levy Frères. (Original work published 1871)

http://dx.doi.org/10.7565/landp.v9i1.1703 
Serça, I. (2015). La ponctuation est l'anatomie du langage. Maylis de Kerangal. Littératures, 72, 173-184.

Whitehead, A. N. (1978). Process and reality [corrected edition]. New York, NY: Free Press. (Original work published 1929)

Wisnik, J. M. (2013). Chopin e os domínios do piano. Teresa, 12-13, 14-46.

Retrieved from www.revistas.usp.br/teresa/article/view/98896 